\title{
A ventilation intervention study in classrooms to improve indoor air quality: the FRESH study
}

\author{
Jeannette TM Rosbach ${ }^{1,2}$, Machiel Vonk ${ }^{2 *}$, Frans Duijm², Jan T van Ginkel ${ }^{3}$, Ulrike Gehring ${ }^{1}$ and Bert Brunekreef ${ }^{1,4}$
}

\begin{abstract}
Background: Classroom ventilation rates often do not meet building standards, although it is considered to be important to improve indoor air quality. Poor indoor air quality is thought to influence both children's health and performance. Poor ventilation in The Netherlands most often occurs in the heating season. To improve classroom ventilation a tailor made mechanical ventilation device was developed to improve outdoor air supply. This paper studies the effect of this intervention.

Methods: The FRESH study (Forced-ventilation Related Environmental School Health) was designed to investigate the effect of a $\mathrm{CO}_{2}$ controlled mechanical ventilation intervention on classroom $\mathrm{CO}_{2}$ levels using a longitudinal cross-over design. Target $\mathrm{CO}_{2}$ concentrations were 800 and 1200 parts per million (ppm), respectively. The study included 18 classrooms from 17 schools from the north-eastern part of The Netherlands, 12 experimental classrooms and 6 control classrooms. Data on indoor levels of $\mathrm{CO}_{2}$, temperature and relative humidity were collected during three consecutive weeks per school during the heating seasons of 2010-2012. Associations between the intervention and weekly average indoor $\mathrm{CO}_{2}$ levels, classroom temperature and relative humidity were assessed by means of mixed models with random school-effects.
\end{abstract}

Results: At baseline, mean $\mathrm{CO}_{2}$ concentration for all schools was 1335 ppm (range: 763-2000 ppm). The intervention was able to significantly decrease $\mathrm{CO}_{2}$ levels in the intervention classrooms $(F(2,10)=17.59, \mathrm{p}<0.001)$, with a mean decrease of 491 ppm. With the target set at 800 ppm, mean $\mathrm{CO}_{2}$ was 841 ppm (range: 743-925 ppm); with the target set at 1200 ppm, mean $\mathrm{CO}_{2}$ was 975 ppm (range: 887-1077 ppm).

Conclusions: Although the device was not capable of precisely achieving the two predefined levels of $\mathrm{CO}_{2}$, our study showed that classroom $\mathrm{CO}_{2}$ levels can be reduced by intervening on classroom ventilation using a $\mathrm{CO}_{2}$ controlled mechanical ventilation system.

Keywords: Ventilation, Schools, Carbon dioxide, Indoor air quality, Intervention

\section{Background}

Children spend much of their time in schools; it is the indoor environment where they spend most of their time besides in their home. It is therefore important that schools have a good indoor air quality (IAQ). Classroom ventilation was already recognised as an important determinant of indoor air quality in the beginning of the $20^{\text {th }}$ century [1]; however, even recent studies showed that classroom ventilation rates do not meet building standards. Two studies performed in The Netherlands in 2007 showed that more than $80 \%$ of

\footnotetext{
* Correspondence: machiel.vonk@ggd.groningen.nl

${ }^{2}$ Department of Environmental Health, Municipal Health Services Groningen, P.O. Box 584, 9700 AN, Groningen, The Netherlands

Full list of author information is available at the end of the article
}

the schools exceeded $\mathrm{CO}_{2}$ levels of 1200 parts per million (ppm) during classroom occupation [2,3], which in The Netherlands is the advised maximum $\mathrm{CO}_{2}$ concentration for classrooms $[4,5]$.

Poor IAQ has found to be associated with a negative impact on health [6,7]. However, these reviews mainly focussed on office buildings and their occupants. Daisey et al. [8] reviewed the literature published until 1999 with a specific focus on schools. With respect to ventilation, most studies merely investigated the amount of ventilation and conclude that ventilation is inadequate in many classrooms, which may possibly lead to health related symptoms. As of 1999, Daisy et al. [8] found two studies that specifically looked at the relationship between

C Biomed Central

the article

(c) 2013 Rosbach et al.; licensee BioMed Central Ltd. This is an open access article distributed under the terms of the Creative Commons Attribution License (http://creativecommons.org/licenses/by/2.0), which permits unrestricted use, distribution, and reproduction in any medium, provided the original work is properly cited. 
ventilation and the prevalence of health related symptoms. However, the results of these two studies were inconsistent and thus the authors stress the need of more studies looking into the relationship between IAQ in schools and health. The recent review of Sundell et al. [9] looked into the available literature until 2005 and discussed five articles that have studied the school environment. They concluded from these studies that low ventilation rates are associated with increased absenteeism and more respiratory symptoms in school children, but emphasise that there is too little data available to make firm conclusions. Furthermore, they also stressed the need for more studies on the relationship between ventilation and health, especially in buildings other than offices. Since 2005, more studies on the relationship between ventilation of schools and health have been published, for example two articles relating ventilation rates in schools to illness absenteeism of the students $[10,11]$. Both of these studies found that lower ventilation rates are associated with higher absenteeism. Another study, on the effect of the implementation of a new ventilation system in schools, found that after installation less asthmatic symptoms were reported and exposure to airborne pollutants decreased [12].

Apart from the effects of IAQ on health, research has also focussed on the effects of ventilation on human performance. Mendell and Heath [13] reviewed the literature available until 2003 on the possible effects of poor IAQ on students' performance and concluded that there is suggestive evidence for an association between ventilation rates and the attention and performance of students, two prerequisites of an efficient learning process. Since this review, various papers have been published regarding this topic. An observational study reported an association between classroom ventilation rates and students' achievements on a standardised academic performance test. Based on their study the authors suggest a linear relationship between poorer classroom ventilation and lower academic achievement [14]. Four studies have used an experimental design [15-18]. Findings of these studies are inconsistent, but comparisons of the studies are difficult due to differences in study design and outcome parameters.

The levels of $\mathrm{CO}_{2}$ that exist indoor have long been thought to have no direct impact on occupant's health or performance [19], but to be primarily an indicator of the level of ventilation. It has been hypothesised that the observed associations between ventilation levels and health or performance result from the fact that ventilation does not only affect the level of indoor $\mathrm{CO}_{2}$, but also levels of other pollutants in the indoor environment that are able to cause these adverse effects [20]. However, Satish et al. [20] conducted a laboratory experiment on the direct effects of $\mathrm{CO}_{2}$ at normally occurring indoor concentrations on human decision making. Their study suggests that, compared to $\mathrm{CO}_{2}$ concentrations of $600 \mathrm{ppm}$, at $1000 \mathrm{ppm}$ and $2500 \mathrm{ppm}$ a reduction in decision-making performance occurs. This may indicate the importance of considering $\mathrm{CO}_{2}$ in itself as an air pollutant. However, they stress that confirmation of their findings is needed.

Since there is still a need for more experimental evidence with respect to the relationship of classroom ventilation and its effect on both respiratory health and cognitive performance, the FRESH study (Forced-ventilation Related Environmental School Health) was designed. The aim of this study is to investigate whether an intervention can be used to improve classroom IAQ by increasing classroom ventilation and whether this intervention affects children's cognitive performance and/or respiratory health. In this paper, we focus on the performance of the ventilation system in terms of achieved classroom $\mathrm{CO}_{2}$ concentrations.

\section{Methods}

\section{Study design}

The FRESH study has been designed as an intervention study with two experimental groups and one control group. Differences between the two experimental groups were created using a cross-over design. Data collection for this study took place at 17 primary schools during the heating seasons (October-April) of 2010-2011 and 2011-2012. In the first school year, ten schools participated, in the second year eight. One school participated in both the first and the second year, but with a different student population. With this exception, per school, one classroom was studied, with repeated measurements during three consecutive weeks. The first week served as baseline period, with measurements of normally existing $\mathrm{CO}_{2}$ levels and ventilation according to the teachers own preference. In the following two weeks, in the 12 intervention classrooms the concentrations of $\mathrm{CO}_{2}$ were maintained at pre-set levels of 800 and $1200 \mathrm{ppm}$, established with a mobile, custom-made mechanical ventilation device. During these weeks, the teachers were asked not to ventilate the classroom by opening doors or windows. In the six schools that acted as the control group, no intervention on ventilation took place. In these classrooms, $\mathrm{CO}_{2}$ levels were monitored and teachers were allowed to ventilate as they preferred.

\section{Participating schools}

In total 18 classrooms ( $7^{\text {th }}$ grade children, ages $10-11$ years) from 17 different schools were investigated in the FRESH study. These schools were all located in two regions in the north and north-eastern part of The Netherlands with comparatively low concentrations of ambient air pollutants (Zwolle and Groningen). Each region provided nine classrooms for the study. In the Zwolle region it was more difficult to find schools willing to participate, so that 
in the second year of the study, one school (but with a different student population) participated again. Schools were randomly selected, excluding those that were within $250 \mathrm{~m}$ of a busy road or highway. A total of 80 schools were asked to participate before the planned number of 18 classrooms was achieved (23\% response). Many schools that did not participate in the study valued the FRESH study as important, but were too busy to take part in the (relatively invasive) FRESH study. Schools were randomly allocated to the three study arms, but were allocated to the control arm when for practical reasons it was not possible to install the ventilation system (4 schools). The exact size of the classrooms has not been measured, but classrooms in The Netherlands measure approximately $50 \mathrm{~m}^{2}$. The average number of students in the studied classrooms was 26, per classroom one teacher was present. All studied classrooms relied on natural ventilation through opening doors and windows to provide fresh air. Table 1 provides more information on the schools.

\section{Intervention}

In 12 schools we changed the classroom ventilation, using a specially designed and installed mechanical ventilation device. Based on a design of providing a stable ventilation flow with an adjustable outdoor air supply rate, this device consisted of an exterior constant flow fan (LAAHP12, Shandong LARK Central Air Condition Co., China) placed outdoors. Within the device outdoor air was mixed with indoor air derived from the classroom via the return system. The mixing ratio between indoor and outdoor air was depended on the setting of the targeted $\mathrm{CO}_{2}$ concentration and was adjusted by means of a valve in the inlet of the outdoor air supply system. The mixture of indoor and outdoor air was than heated before being introduced into the classroom with a flow of approximately $1400 \mathrm{~m}^{3} / \mathrm{h}$. Simple ducting (diameter $355 \mathrm{~mm}$ ) lead the air without filtering into the building through a tailor made window pane. In the classrooms, the air was distributed through a flexible, perforated fabric air sock. A non-flexible duct was used for air exhaust. Both the air sock and exhaust duct were attached to the ceiling of the classroom. In Figure 1 the ventilation device and the installation within a classroom are shown.

The device was $\mathrm{CO}_{2}$ controlled, using a real-time, self-calibrating $\mathrm{CO}_{2}$ sensor (Telair $6613 \mathrm{CO}_{2}$ module, GE Measurement \& Control, USA) to adjust the amount of outdoor air supplied, in order to achieve a target steady-state $\mathrm{CO}_{2}$ concentration in the classroom. This $\mathrm{CO}_{2}$ sensor was located at one of the walls of the classroom, at approximately $1.5 \mathrm{~m}$ from the floor, where possible not close to windows and doors. By means of the recirculation and constant air flow blinding of students, teachers and field investigators to the level of outdoor air supply was established. As classrooms in The Netherlands have approximately the same size, one single ventilation flow was chosen (approximately $1400 \mathrm{~m}^{3} / \mathrm{h}$ ) that was enough to realise the targeted $\mathrm{CO}_{2}$ concentration without creating disturbingly high air flows within the classroom.

For this study, pre-set levels of 800 and 1200 ppm $\mathrm{CO}_{2}$ were defined. The lower level represents the level

Table 1 School characteristics

\begin{tabular}{lllll}
\hline School & n students & Study region & Condition & Study period \\
\hline E1 & 31 & Zwolle & Intervention 1 (800-1200) & Jan 2011 \\
E2 & 27 & Zwolle & Intervention 1 (800-1200) & March 2011 \\
E3 & 22 & Zwolle & Intervention 1 (800-1200) & Nov 2011 \\
E4 & 30 & Groningen & Intervention 1 (800-1200) & Jan 2011 \\
E5 & 27 & Groningen & Intervention 1 (800-1200) & Jan 2012 \\
E6 & 25 & Groningen & Intervention 1 (800-1200) & March 2012 \\
E7 & 23 & Zwolle & Intervention 2 (1200-800) & Feb 2012 \\
E8 & 23 & Zwolle & Intervention 2 (1200-800) & Jarch 2012 2012 \\
E9 & 22 & Zwolle & Intervention 2 (1200-800) & Nov 2010 \\
E10 & 23 & Groningen & Intervention 2 (1200-800) & March 2011 \\
E11 & 29 & Groningen & Intervention 2 (1200-800) & Nov 2011 \\
E12 & 29 & Groningen & Intervention 2 (1200-800) & Oct 2010 \\
C1 & 36 & Zwolle & Control & Jan 2011 \\
C2 & 25 & Zwolle & Control & March 2011 \\
C3 & 22 & Zwolle & Control & Jan 2011 \\
C4 & 28 & Groningen & Control & March 2011 \\
C5 & 18 & Groningen & Control & March 2012 \\
C6 & 29 & Groningen & Control & \\
\end{tabular}




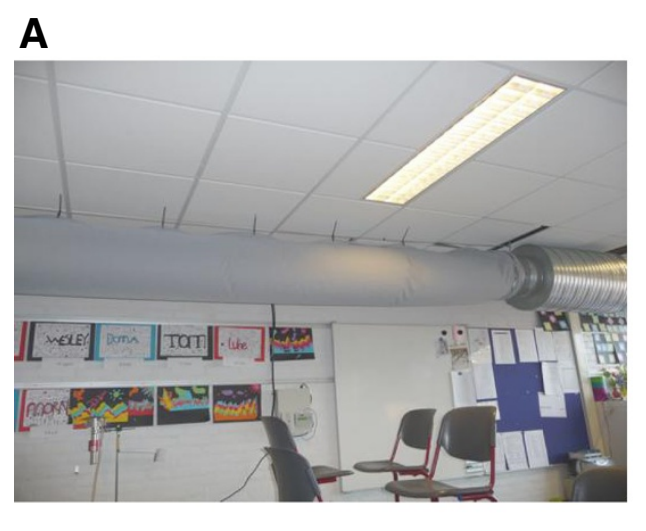

C

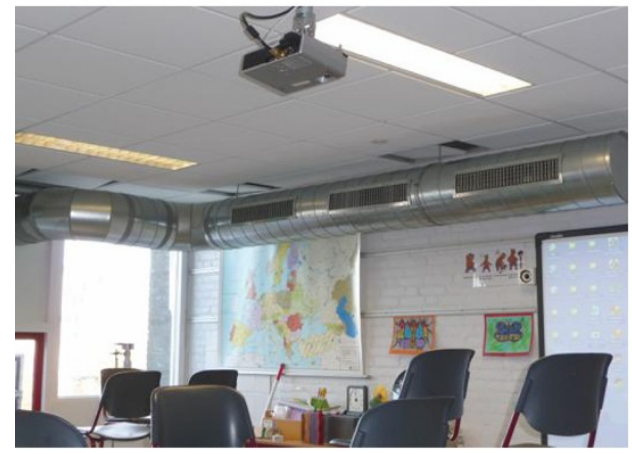

B
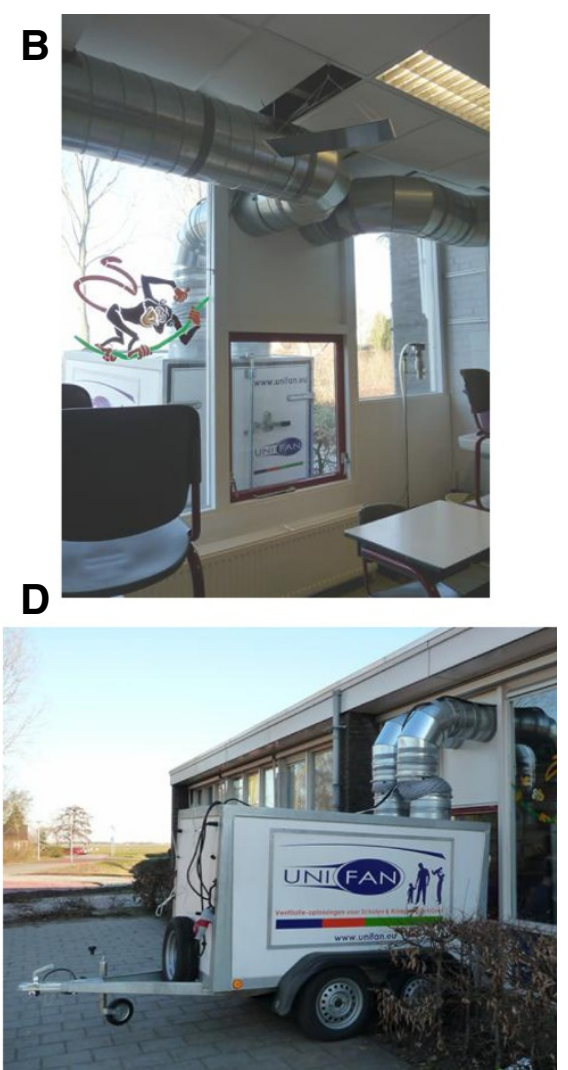

Figure $\mathbf{1}$ Installation of the ventilation intervention in a classroom. $\mathbf{A}=$ air sock for air supply, $\mathbf{B}=$ tailor made window pane, $\mathbf{C}=$ non-flexible duct for air exhaustion, $\mathbf{D}=$ ventilator.

advised by the joint Dutch Municipal Health Services. The upper level represents the basis on which Dutch Building Regulations have formulated the minimal achievable air flow for the design of new schools $[4,5]$. To maintain a cross-over in the design, in half of the classrooms, we started ventilating at $800 \mathrm{ppm}$, the other six schools started with a setting of $1200 \mathrm{ppm}$. In the third week of the study, the ventilation regime changed.

To prevent thermal discomfort and create a more or less stable classroom temperature, the device was equipped with an air pump able to both heat and cool the outdoor air before it was introduced into the classrooms. Classroom temperature was set at $21^{\circ} \mathrm{C}$, to minimize differences between the schools. Based on measurements of a realtime temperature sensor (located at the same position as the $\mathrm{CO}_{2}$ sensor) cooling or heating of the supplied air was adjusted according to the classroom temperature. As the experiment was carried out in winter seasons, classroom temperature was higher than outdoor temperature. Even though no measurements were performed of the exact temperature of supplied air, it is to be expected that this air was heated. When classroom temperature exceeded $21^{\circ} \mathrm{C}$, colder air was supplied to lower the indoor temperature. Furthermore, the system was designed to maintain system noise below $35 \mathrm{~dB}(\mathrm{~A})$. This value has shown to be the threshold for annoyance and disturbance [21].

\section{Indoor measurements}

During the study weeks, each classroom was equipped with two data loggers (GRP-300 Pro (ATAL, The Netherlands) in study region 1 and ATV-IAQ set (ATAL, The Netherlands) in study region 2) for $\mathrm{CO}_{2}$, temperature and relative humidity. These data loggers were calibrated each year by the manufacturer. The loggers were positioned as much as possible at the height of the desks of the pupils and on the opposite sides of the classroom. Log interval was 4 minutes. From the two data loggers the average was taken to represent classroom $\mathrm{CO}_{2}$, temperature and relative humidity. All data reported in this paper are restricted to periods of actual classroom occupation excluding breaks and periods when students were elsewhere (e.g. gym).

\section{Outdoor measurements}

The selected schools were not located to obvious sources of $\mathrm{CO}_{2}$, therefore no continuous measurements of outdoor $\mathrm{CO}_{2}$ concentrations were performed. To get an indication of outdoor $\mathrm{CO}_{2}$ concentrations, short time frame measurements of approximately 5 minutes were performed just 
outside the school building, using the same type of $\mathrm{CO}_{2}$ data loggers that were used for indoor measurements. Measurements took place at the beginning and end of each week. Data on 24 h-average outdoor temperature and relative humidity were obtained from the two weather stations (Eelde and Hoogeveen) of the Royal Netherlands Meteorological Institute closest to the study regions.

\section{Ethical approval}

The study design and protocols have approved by the 'Central Committee on Research involving Human Subjects' (CCMO, The Hague) on February 23, 2010 and is registered under number 120620026.

\section{Statistical analysis}

The data were analysed using PASW Statistics 18 and SAS 9.2. Significance was tested against an $\alpha=0.05$. The effect of the intervention, as well as differences between the two settings of the intervention $(800 \mathrm{ppm}$ and $1200 \mathrm{ppm}$ ) were tested by means of mixed models with random school intercepts to take into account the dependency of the repeated measurements performed in the same classrooms.

\section{Results}

Mean indoor $\mathrm{CO}_{2}$ concentrations, temperature and relative humidity during classroom occupation per school per week are presented in Tables 2, 3 and 4.
During the first week (baseline) mean classroom $\mathrm{CO}_{2}$ concentration was $1335 \mathrm{ppm}(\mathrm{sd}=325)$ with a range of 763-2000 ppm. In the classrooms allocated to become intervention schools, mean $\mathrm{CO}_{2}$ concentration was $1399 \mathrm{ppm}(\mathrm{sd}=350)$, the control classrooms had an average $\mathrm{CO}_{2}$ concentration of $1208 \mathrm{ppm}(\mathrm{sd}=244)$. Only two classrooms (E10 and C5) had mean $\mathrm{CO}_{2}$ concentration lower than $800 \mathrm{ppm}$ at baseline, and another five classrooms had mean $\mathrm{CO}_{2}$ concentrations lower than 1200 ppm.

In the second week, we started the intervention in 12 classrooms. In those 12 classrooms, on average we decreased mean $\mathrm{CO}_{2}$ with $491 \mathrm{ppm}$ compared to baseline ( $\mathrm{sd}=324$, range: $-1085-124 \mathrm{ppm})$. With the setting of the ventilation set at $800 \mathrm{ppm}$, the average $\mathrm{CO}_{2}$ concentration was $841 \mathrm{ppm}(\mathrm{sd}=65)$ with a range of 743-925 ppm. When set at $1200 \mathrm{ppm}$, the average $\mathrm{CO}_{2}$ concentration was $975 \mathrm{ppm}(\mathrm{sd}=73$, range: $887-1077 \mathrm{ppm})$. In the control classrooms, during the second and third week, $\mathrm{CO}_{2}$ concentrations ranged from 740 to $2328 \mathrm{ppm}$, with an average mean $\mathrm{CO}_{2}$ concentration of $1350 \mathrm{ppm}(\mathrm{sd}=486)$. Figure 2 displays the boxplot of $\mathrm{CO}_{2}$ concentrations per condition per week. The P98 results confirm that the ventilation device was able to maintain a maximum level of $1200 \mathrm{ppm} \mathrm{CO}_{2}$, whereas it was more difficult to keep $\mathrm{CO}_{2}$ levels below 800 ppm (Table 2).

Table 5 provides the results from our mixed model analysis. From this analysis we can conclude that

Table 2 Mean indoor $\mathrm{CO}_{2}$ concentration (ppm) per school per week

\begin{tabular}{|c|c|c|c|c|c|c|c|c|c|c|c|c|c|}
\hline \multirow[b]{2}{*}{ School } & \multirow[b]{2}{*}{ Condition } & \multicolumn{4}{|c|}{ Week 1} & \multicolumn{4}{|c|}{ Week 2} & \multicolumn{4}{|c|}{ Week 3} \\
\hline & & $n$ & mean & sd & P98 & $\mathrm{n}$ & mean & Sd & P98 & $\mathbf{n}$ & mean & sd & P98 \\
\hline E1 & Intervention 1 (800-1200) & 344 & 1365 & 531 & 2991 & 344 & 902 & 85 & 1128 & 280 & 899 & 83 & 1051 \\
\hline E2 & & 352 & 1337 & 460 & 2351 & 345 & 802 & 74 & 903 & 294 & 908 & 158 & 1126 \\
\hline E3 & & 286 & 1143 & 398 & 2052 & 285 & 753 & 78 & 902 & 320 & 900 & 99 & 1085 \\
\hline E4 & & 215 & 1648 & 353 & 2395 & 312 & 843 & 48 & 930 & 350 & 1059 & 99 & 1203 \\
\hline E5 & & 347 & 1466 & 330 & 2322 & 295 & 906 & 147 & 1347 & 257 & 1063 & 134 & 1276 \\
\hline E6 & & 255 & 2000 & 602 & 3321 & 270 & 915 & 44 & 993 & 297 & 1077 & 96 & 1195 \\
\hline E7 & Intervention 2 (1200-800) & 356 & 1323 & 291 & 1963 & 356 & 993 & 140 & 1221 & 356 & 820 & 85 & 937 \\
\hline E8 & & 354 & 1049 & 158 & 1313 & 321 & 905 & 130 & 1124 & 353 & 743 & 87 & 887 \\
\hline E9 & & 265 & 1763 & 423 & 2507 & 301 & 975 & 84 & 1159 & 336 & 764 & 51 & 853 \\
\hline E10 & & 222 & 763 & 131 & 1153 & 272 & 887 & 119 & 1150 & 334 & 858 & 76 & 938 \\
\hline E11 & & 367 & 1762 & 625 & 3064 & 352 & 995 & 151 & 1168 & 336 & 858 & 105 & 1018 \\
\hline E12 & & 347 & 1171 & 213 & 1553 & 343 & 1034 & 108 & 1182 & 309 & 925 & 70 & 1045 \\
\hline $\mathrm{C} 1$ & Control & 380 & 1393 & 483 & 2446 & 379 & 2137 & 591 & 3179 & 379 & 2328 & 483 & 3197 \\
\hline$C 2$ & & 342 & 1176 & 289 & 1694 & 342 & 1100 & 255 & 1523 & 342 & 1249 & 347 & 1838 \\
\hline $\mathrm{C} 3$ & & 351 & 1112 & 333 & 1789 & 335 & 1132 & 304 & 1827 & 327 & 996 & 240 & 1527 \\
\hline C4 & & 350 & 1389 & 425 & 2264 & 340 & 1274 & 357 & 1982 & 340 & 1191 & 389 & 2362 \\
\hline$C 5$ & & 353 & 779 & 177 & 1166 & 328 & 864 & 159 & 1234 & 312 & 740 & 151 & 1098 \\
\hline C6 & & 282 & 1399 & 311 & 1975 & 344 & 1677 & 377 & 2318 & 336 & 1509 & 538 & 2879 \\
\hline
\end{tabular}


Table 3 Mean indoor temperature $\left({ }^{\circ} \mathrm{C}\right)$ per school per week

\begin{tabular}{|c|c|c|c|c|c|c|c|c|c|c|}
\hline \multirow[b]{2}{*}{ School } & \multirow[b]{2}{*}{ Condition } & \multicolumn{3}{|c|}{ Week 1} & \multicolumn{3}{|c|}{ Week 2} & \multicolumn{3}{|c|}{ Week 3} \\
\hline & & $\mathrm{n}$ & mean & sd & $n$ & mean & sd & $n$ & mean & sd \\
\hline E1 & Intervention 1 (800-1200) & 344 & 20.2 & 1.4 & 344 & 20.3 & 0.9 & 280 & 20.3 & 0.9 \\
\hline E2 & & 352 & 21.1 & 1.1 & 345 & 19.1 & 0.8 & 294 & 19.1 & 0.8 \\
\hline E3 & & 286 & 21.0 & 0.9 & 285 & 19.3 & 1.7 & 320 & 19.3 & 1.7 \\
\hline E4 & & 215 & 19.2 & 1.1 & 312 & 18.5 & 1.2 & 350 & 18.5 & 1.2 \\
\hline E5 & & 347 & 21.2 & 1.1 & 295 & 21.4 & 1.5 & 257 & 21.4 & 1.5 \\
\hline E6 & & 255 & 20.4 & 1.0 & 270 & 20.2 & 0.5 & 297 & 20.2 & 0.5 \\
\hline E7 & Intervention 2 (1200-800) & 356 & 21.6 & 0.9 & 356 & 20.4 & 1.0 & 356 & 20.4 & 1.0 \\
\hline E8 & & 354 & 19.2 & 0.8 & 321 & 19.7 & 1.2 & 353 & 19.7 & 1.2 \\
\hline E9 & & 265 & 21.8 & 1.5 & 301 & 20.8 & 1.9 & 336 & 20.8 & 1.9 \\
\hline E10 & & 222 & 23.0 & 0.8 & 272 & 23.3 & 0.9 & 334 & 23.3 & 0.9 \\
\hline E11 & & 367 & 20.9 & 1.1 & 352 & 20.8 & 1.3 & 336 & 20.8 & 1.3 \\
\hline E12 & & 347 & 22.0 & 1.3 & 343 & 21.1 & 0.8 & 309 & 21.1 & 0.8 \\
\hline C1 & Control & 380 & 22.6 & 1.2 & 379 & 20.6 & 1.5 & 379 & 20.6 & 1.5 \\
\hline$C 2$ & & 342 & 21.2 & 0.8 & 342 & 20.7 & 0.6 & 342 & 20.7 & 0.6 \\
\hline C3 & & 351 & 19.8 & 1.3 & 335 & 20.1 & 1.6 & 327 & 20.1 & 1.6 \\
\hline C4 & & 350 & 20.9 & 0.6 & 340 & 21.8 & 0.8 & 340 & 21.8 & 0.8 \\
\hline C5 & & 353 & 20.4 & 1.2 & 328 & 22.3 & 0.6 & 312 & 22.3 & 0.6 \\
\hline C6 & & 282 & 19.7 & 1.0 & 344 & 20.1 & 1.0 & 336 & 20.1 & 1.0 \\
\hline
\end{tabular}

Table 4 Mean indoor relative humidity (\%) per school per week

\begin{tabular}{|c|c|c|c|c|c|c|c|c|c|c|}
\hline \multirow[b]{2}{*}{ School } & \multirow[b]{2}{*}{ Condition } & \multicolumn{3}{|c|}{ Week 1} & \multicolumn{3}{|c|}{ Week 2} & \multicolumn{3}{|c|}{ Week 3} \\
\hline & & $n$ & mean & sd & $n$ & mean & sd & $\mathbf{n}$ & mean & sd \\
\hline E1 & Intervention 1 (800-1200) & 344 & 33.6 & 6.4 & 344 & 38.0 & 11.7 & 280 & 30.3 & 4.0 \\
\hline E2 & & 352 & 30.4 & 6.2 & 345 & 28.3 & 10.4 & 294 & 44.9 & 6.8 \\
\hline E3 & & 286 & 54.4 & 5.6 & 285 & 41.5 & 7.6 & 320 & 32.0 & 8.6 \\
\hline E4 & & 215 & 45.5 & 7.8 & 312 & 35.3 & 6.8 & 350 & 37.3 & 4.2 \\
\hline E5 & & 347 & 49.8 & 6.2 & 295 & 30.7 & 4.0 & 257 & 32.7 & 3.2 \\
\hline E6 & & 255 & 48.2 & 3.4 & 270 & 40.2 & 3.4 & 297 & 42.1 & 4.4 \\
\hline E7 & Intervention 2 (1200-800) & 356 & 40.1 & 5.6 & 356 & 27.9 & 4.6 & 356 & 29.2 & 3.0 \\
\hline E8 & & 354 & 42.7 & 3.9 & 321 & 42.4 & 3.7 & 353 & 40.4 & 3.0 \\
\hline E9 & & 265 & 27.1 & 4.4 & 301 & 15.7 & 3.0 & 336 & 30.2 & 2.9 \\
\hline E10 & & 222 & 48.7 & 4.0 & 272 & 31.4 & 2.9 & 334 & 32.6 & 1.6 \\
\hline E11 & & 367 & 46.6 & 7.9 & 352 & 31.4 & 7.3 & 336 & 39.9 & 7.5 \\
\hline E12 & & 347 & 53.8 & 4.7 & 343 & 41.9 & 4.8 & 309 & 33.0 & 5.9 \\
\hline $\mathrm{C} 1$ & Control & 380 & 62.3 & 2.9 & 379 & 54.6 & 4.5 & 379 & 55.0 & 2.2 \\
\hline $\mathrm{C} 2$ & & 342 & 33.4 & 6.5 & 342 & 32.7 & 6.3 & 342 & 37.3 & 4.2 \\
\hline $\mathrm{C} 3$ & & 351 & 42.3 & 4.3 & 335 & 43.7 & 6.5 & 327 & 47.0 & 6.3 \\
\hline C4 & & 350 & 37.1 & 4.4 & 340 & 39.6 & 7.6 & 340 & 36.0 & 5.7 \\
\hline C5 & & 353 & 35.9 & 4.1 & 328 & 35.8 & 6.9 & 312 & 40.1 & 5.3 \\
\hline C6 & & 282 & 27.6 & 4.2 & 344 & 29.4 & 4.2 & 336 & 42.8 & 4.0 \\
\hline
\end{tabular}




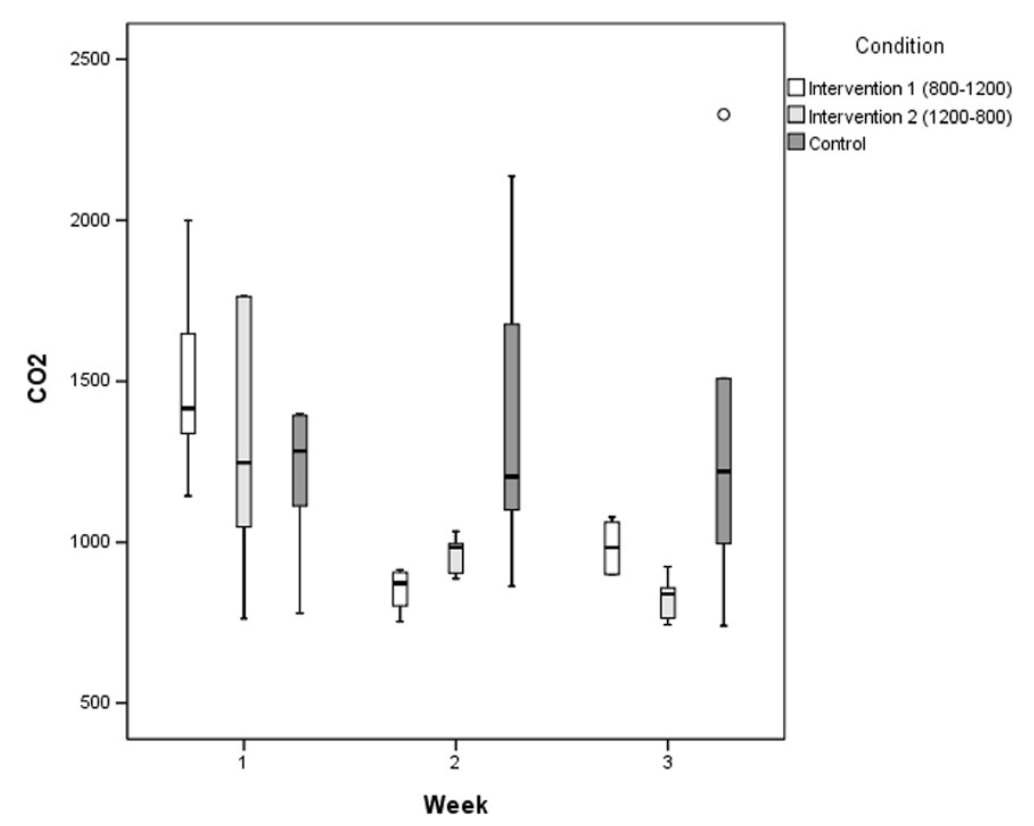

Figure 2 Boxplot of mean $\mathrm{CO}_{2}$ concentration per condition per week.

classroom $\mathrm{CO}_{2}$ levels were statistically significantly decreased during the intervention $(F(2,10)=17.59$, $\mathrm{p}<0.001)$. Compared to baseline, the estimated mean decrease in $\mathrm{CO}_{2}$ with the setting at $800 \mathrm{ppm}$ was $558 \mathrm{ppm}(\mathrm{SE}=97.8)$. For the setting of $1200 \mathrm{ppm}$, the estimated mean decrease was $424 \mathrm{ppm}(\mathrm{SE}=97.8)$. The mean difference in decrease compared to baseline between the two settings of the intervention was $134 \mathrm{ppm}$ $(\mathrm{SE}=29.3, \mathrm{t}(10)=4.57, \mathrm{p}=0.001)$.

The result of implementation of the ventilation intervention and its effect on the $\mathrm{CO}_{2}$ in a classroom is illustrated in Figure 3. This graph displays the $\mathrm{CO}_{2}$ concentration during the three weeks of the study in one of the experimental classrooms. The graph shows how in the first week, high $\mathrm{CO}_{2}$ peak concentrations exist, which no longer occur during the second and third week. Also, it shows how the $\mathrm{CO}_{2}$ concentrations are much more stable in the two intervention weeks. Furthermore, the graph shows the (slight) difference in $\mathrm{CO}_{2}$ concentration during the second (ventilation set at $1200 \mathrm{ppm}$ ) and third (800 ppm) week.

The intervention was designed in such way that classroom temperature did not decrease as a result of supplying (cold) outdoor air. At baseline, average indoor temperature was $20.9^{\circ} \mathrm{C}\left(\mathrm{sd}=1.1\right.$, range: $\left.19.2-23.0^{\circ} \mathrm{C}\right)$. In the intervention classrooms average temperature during weeks two and three was $20.6^{\circ} \mathrm{C}\left(\mathrm{sd}=1.0\right.$, range: $\left.18.5-23.3^{\circ} \mathrm{C}\right)$, in the control classrooms average temperature was $20.9^{\circ} \mathrm{C}$ $\left(\mathrm{sd}=1.2\right.$, range: $\left.18.5-22.5^{\circ} \mathrm{C}\right)$. No significant effect of the intervention on classroom temperature was found $(\mathrm{F}(2,10)=2.13, \mathrm{p}=0.170)$, nor on differences between the two intervention settings (Table 5).

Indoor relative humidity at baseline was $42.2 \%(\mathrm{sd}=9.9$, range: $27.1-62.3 \%$ ), in weeks two and three average relative humidity was $41.2 \%$ ( $\mathrm{sd}=8.0$, range: $29.4-55.0 \%$ ) in the control classrooms and $34.5 \%(\mathrm{sd}=6.6$, range: $16.7-44.9 \%)$ in the intervention classrooms. This decrease in relative humidity due to the intervention appeared to be statistically significant $(\mathrm{F}(2,10)=4.16, \mathrm{p}=0.049)$. No significant difference between the two intervention conditions was found (Table 5).

During the study, outdoor $\mathrm{CO}_{2}$ concentration was on average $471 \mathrm{ppm}(\mathrm{sd}=53$, range: $350-660 \mathrm{ppm})$, mean outdoor temperature was $4.7^{\circ} \mathrm{C}(\mathrm{sd}=5.1$, range: -12.7 $16.9^{\circ} \mathrm{C}$ ), and mean outdoor relative humidity was $87.1 \%$ $(\mathrm{sd}=8.5$, range: $54-100 \%)$.

Table 5 Mean decrease of $\mathrm{CO}_{2}(\mathrm{ppm})$, temperature $\left({ }^{\circ} \mathrm{C}\right)$ or relative humidity $(\%)$ compared to baseline measurements

\begin{tabular}{|c|c|c|c|c|c|c|c|c|c|}
\hline \multirow[b]{2}{*}{ Setting } & \multicolumn{3}{|c|}{$\mathrm{CO}_{2}$ (ppm) } & \multicolumn{3}{|c|}{$\mathrm{T}\left({ }^{\circ} \mathrm{C}\right)$} & \multicolumn{3}{|c|}{ RH (\%) } \\
\hline & mean decrease & SE & $\mathrm{p}$ & mean decrease & SE & $p$ & mean decrease & SE & $\mathrm{p}$ \\
\hline $800 \mathrm{ppm}$ & 558 & 97.8 & $<0.001$ & 0.56 & 0.35 & 0.144 & 8.5 & 2.4 & 0.005 \\
\hline 1200 ppm & 424 & 97.8 & 0.002 & 0.10 & 0.35 & 0.784 & 9.3 & 2.4 & 0.003 \\
\hline Difference between 800 and 1200 ppm & 134 & 29.3 & 0.001 & 0.46 & 0.24 & 0.088 & 0.8 & 2.3 & 0.734 \\
\hline
\end{tabular}




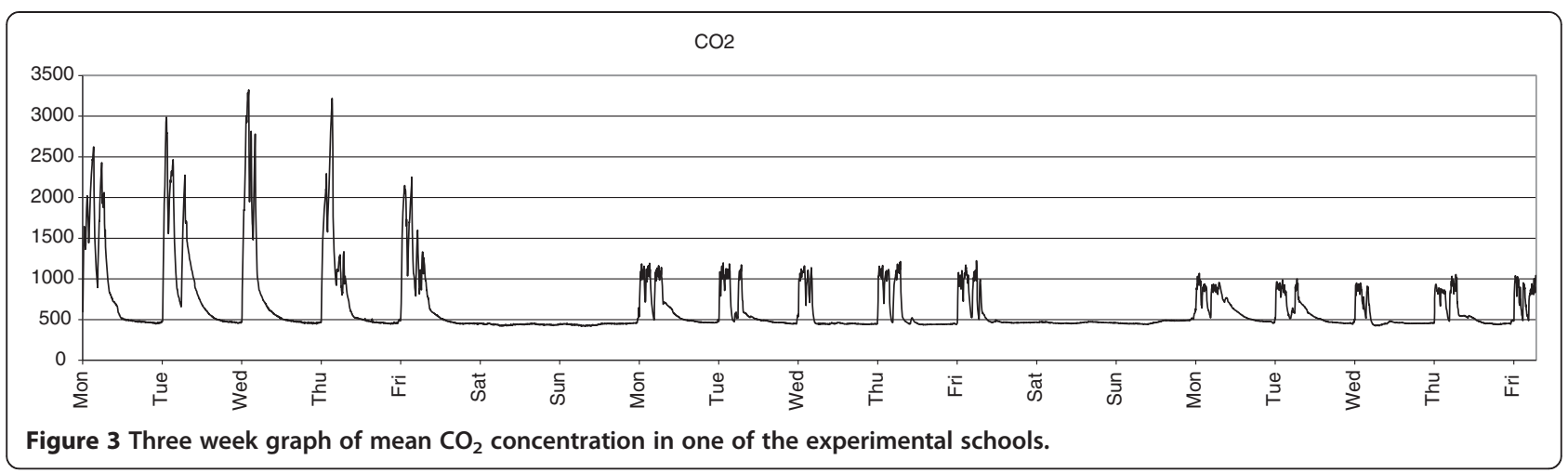

\section{Discussion}

This study showed that it is possible to use a portable, tailor made mechanical ventilation device to improve outdoor air supply in schools during the heating season. In the classrooms where we intervened we found an average decrease of $491 \mathrm{ppm} \mathrm{CO}_{2}$ with, however, little difference between the two experimental conditions. The target value of $1200 \mathrm{ppm}$ was more than met, however the target value of $800 \mathrm{ppm}$ proved to be more difficult to achieve. To what extent this is due to differences in $\mathrm{CO}_{2}$ concentrations measured at the location of the system sensor and the location of our two data loggers we do not know as the system sensor was unable to log the $\mathrm{CO}_{2}$ concentrations, nor was it equipped with a display enabling us to read measured $\mathrm{CO}_{2}$ concentrations by the system sensor. Another possible explanation could be that the ventilation device appeared to have not enough capacity to lower $\mathrm{CO}_{2}$ concentration to $800 \mathrm{ppm}$ during classroom occupation. Technical specifications suggest that this should not have been the case, however, we did not measure true air displacement of our installation in the field as we focussed our study design on obtaining specific indoor $\mathrm{CO}_{2}$ concentrations rather than on achieving specific ventilation rates.

In all but one classroom, the intervention was able to decrease $\mathrm{CO}_{2}$ concentration. The level of decrease varied per classroom, as this is related to $\mathrm{CO}_{2}$ concentration measured at baseline. The highest decrease in $\mathrm{CO}_{2}$ concentration was observed in school E6, where we lowered mean $\mathrm{CO}_{2}$ concentration from $2000 \mathrm{ppm}$ to $915 \mathrm{ppm}$. In one school $\mathrm{CO}_{2}$ levels slightly increased after implementation of the intervention (school E10), this however was due to the high ventilation rate in the baseline week which produced low $\mathrm{CO}_{2}$ concentrations that we did not need to lower further. In seven schools we found baseline $\mathrm{CO}_{2}$ concentrations lower than $1200 \mathrm{ppm}$, in two schools the average $\mathrm{CO}_{2}$ concentration in the first week was lower than $800 \mathrm{ppm}$. This number is higher that we had expected based on the studies from 2007 [2,3]. It is plausible that since 2007 ventilation behaviour in schools has improved. The study by Versteeg [2] resulted in media-attention and a political debate in the Dutch government. Moreover, it could well be that the participation in the FRESH study directly influenced the teachers' (and pupils') awareness of the importance of proper classroom ventilation, resulting in relatively low baseline $\mathrm{CO}_{2}$ concentrations. The decreased relative humidity indoors during the intervention period may be explained by differences in outdoor and indoor temperature between baseline and intervention periods. Especially in cold climates, low indoor relative humidity is associated with increased ventilation rates [7].

Recently various other classroom ventilation intervention studies have been published, most of them predefined a contrast aimed to be achieved by the intervention. One of these studies, by Twardella et al. [16] adjusted the mechanical ventilation within 20 classrooms of six schools. They either up- or down-regulated the ventilation to achieve $\mathrm{CO}_{2}$ levels of $<1000 \mathrm{ppm}$ ('better than usual') or $\mathrm{CO}_{2}$ concentrations of 2000 to $2500 \mathrm{ppm}$ ('worse than usual'). Each condition was implemented for 2 days. They report that it was difficult to regulate the ventilation in such way that the targeted $\mathrm{CO}_{2}$ levels were achieved: only on half of the days of the "worse than usual' condition $\mathrm{CO}_{2}$ concentrations were higher than $2000 \mathrm{ppm}$ and on 22 (of the 40) days of the 'better than usual' condition $\mathrm{CO}_{2}$ concentrations were below $1000 \mathrm{ppm}$. Wargocki and Wyon [22] performed three experiments in which they also adjusted the existing outdoor air supply of the mechanical ventilation of schools by altering the fan capacity. They aimed on increasing ventilation rates from approximately 3 to $10 \mathrm{~L} / \mathrm{s}$ per person. Using a general mass balance equation from measured $\mathrm{CO}_{2}$ concentrations, they were able to estimate the actual effective ventilation rates. In the first experiment estimated mean effective ventilation rates were $4 \mathrm{~L} / \mathrm{s}$ and $8.5 \mathrm{~L} / \mathrm{s}$ per person, in the second experiment these ventilation rates were $3 \mathrm{~L} / \mathrm{s}$ and $6.5 \mathrm{~L} / \mathrm{s}$ per person and in the third experiment $5 \mathrm{~L} / \mathrm{s}$ and $9.5 \mathrm{~L} / \mathrm{s}$ per person. This shows that while they aimed for a threefold increase 
of the ventilation rates, the estimated actual effective ventilation rates were doubled. Bakó-Biró et al. [15] intervened upon classroom ventilation using an installation similar to the one we used in the FRESH study. The biggest difference with our study is that they did not adjust ventilation to achieve predefined levels of $\mathrm{CO}_{2}$, but used the installation to either supply fresh air or recirculate the indoor air in a blinded fashion. As this study aimed at comparing high and low levels of outdoor air supply, with their intervention set at recirculation, they were able to achieve big differences in $\mathrm{CO}_{2}$ concentration between the two experimental conditions. In their study, Smedje and Norbäck were able to study the change in indoor air quality in schools that renewed their ventilation system [12]. They observed that air exchange rates improved, and that associated $\mathrm{CO}_{2}$ concentrations decreased on average by $270 \mathrm{ppm}$ due to a new ventilation system. Furthermore, they also reported a significant decrease in relative humidity in schools with a new ventilation system $(-10 \%)$, compared to schools that did not change their ventilation system $(-2 \%)$.

\section{Conclusions}

Various studies, including our own, show that intervening on classroom ventilation is effective if one wants to change indoor $\mathrm{CO}_{2}$ concentrations. Furthermore, both our own study and the studies of Twardella et al. [16] and Wargocki and Wyon [22] show that field experiments are not comparable with laboratory experiments and that it can be challenging to execute the study as designed. Altogether, our study has shown that classrooms $\mathrm{CO}_{2}$ levels can be significantly reduced by installing a $\mathrm{CO}_{2}$ controlled mechanical ventilation system.

\section{Abbreviations}

IAQ: Indoor air quality; ppm: Parts per million; FRESH: Forced-ventilation related environmental school health (acronym for the study); $\mathrm{m}^{3} / \mathrm{h}$ : Cubic meters per hour; $\mathrm{dB}(\mathrm{A})$ : A-weighted decibels; L/s: Liters per second; sd: Standard deviation; SE: Standard error.

\section{Competing interests}

The authors declare that they have no competing interests.

\section{Author's contributions}

JTMR supported in the design of the study, led and participated in field work in one of the study regions, conducted data processing, analysis, and interpretation and drafted the manuscript. MV contributed to the study and intervention design, participated in data collection in one of the study regions and managed the overall project. MV furthermore helped draft the manuscript. JTVG contributed to the intervention design, participated in data collection in one of the study regions and reviewed the finalised manuscript. UG contributed to the statistical analysis and interpretation of the data and critically reviewed the manuscript. FD and BB conceived of and managed the project and helped prepare and critically review the draft. All authors have read and approved the final manuscript.

\section{Acknowledgements}

The authors would like to thank all schools, and especially the teachers and students of our 18 classes, for their participation in the FRESH study. Furthermore, they thank all colleagues from the Municipal Health Services of Groningen and IJsselland for their support and their contributions to the field work. Gratitude is also expressed to the colleagues of Utrecht University. Financial support for this study was granted by The Netherlands Organisation for Health Research and Development (ZonMw).

\section{Author details}

Institute for Risk Assessment Sciences, Utrecht University, P.O. Box 80178 3508 TD, Utrecht, The Netherlands. ${ }^{2}$ Department of Environmental Health, Municipal Health Services Groningen, P.O. Box 584, 9700 AN, Groningen, The Netherlands. ${ }^{3}$ Department of Environmental Health, Municipal Health Services IJsselland, P.O. Box 1453, 8001 BL, Zwolle, The Netherlands. ${ }^{4}$ Julius Center for Health Sciences and Primary Care, University Medical Center Utrecht, P.O. Box 85500, 3508 GA, Utrecht, The Netherlands.

Received: 2 September 2013 Accepted: 12 December 2013

Published: 17 December 2013

\section{References}

1. Duffield TJ: School ventilation. Its effect on the health of the pupil. Am J Public Health 1927, 17:1226-1229.

2. Versteeg H: Onderzoek naar de kwaliteit van het binnenmilieu in basisscholen. The Hague: Ministerie voor Volkshuisvesting, Ruimtelijke ordening en Milieu; 2007. report 8055 .

3. Meijer G, Duijm F: Binnenmilieu van de openbare scholen in Groningen. Groningen: GGD Groningen; 2009.

4. Health Council of The Netherlands: Indoor air quality in primary schools. The Hague: Health Council of The Netherlands; 2010.

5. Habets T, Van Ass M, Duijm F, Geelen L, Haans L, Van Brederode N: GGDrichtlijn Beoordeling van ventilatie in scholen. Utrecht: GGD Nederland; 2008.

6. Mendell MJ: Non-specific symptoms in office workers: a review and summary of the epidemiologic literature. Indoor Air 1993, 3:227-236.

7. Seppanen OA, Fisk WJ, Mendell MJ: Association of ventilation rates and $\mathrm{CO} 2$ concentrations with health and other responses in commercial and institutional buildings. Indoor Air 1999, 9:226-252.

8. Daisey JM, Angell WJ, Apte MG: Indoor air quality, ventilation and health symptoms in schools: an analysis of existing information. Indoor Air 2003, 13:53-64.

9. Sundell J, Levin H, Nazaroff WW, Cain WS, Fisk WJ, Grimsrud DT, Gyntelberg F, Li Y, Persily AK, Pickering AC, Samet JM, Spengler JD, Taylor ST, Weschler CJ: Ventilation rates and health: multidisciplinary review of the scientific literature. Indoor Air 2011, 21:191-204.

10. Simons E, Hwang S, Fitzgerald EF, Kielb C, Lin S: The impact of school building conditions on student absenteeism in upstate New York. Am J Public Health 2010, 100:1679-1686.

11. Mendell MJ, Eliseeva EA, Davies MM, Spears M, Lobscheid A, Fisk WJ, Apte MG: Association of classroom ventilation with reduced illness absence: a prospective study in California elementary schools. Indoor Air 2013, 23:515-528.

12. Smedje G, Norbäck D: New ventilation systems at select schools in Swedeneffects on asthma and exposure. Arch Environ Health 2000, 55:18-25.

13. Mendell MJ, Heath GA: Do indoor pollutants and thermal conditions in schools influence student performance? A critical review of the literature. Indoor Air 2005, 15:27-52.

14. Haverinen-Shaughnessy U, Moschandreas DJ, Shaughnessy RJ: Association between substandard classroom ventilation rates and students' academic achievement. Indoor Air 2011, 21:121-131.

15. Bakó-Biró Z, Clements-Croome D, Kochhar N, Awbi H, Williams M: Ventilation rates in schools and pupils' performance. Build Environ 2012, 48:215-223.

16. Twardella D, Matzen W, Lahrz T, Burghardt R, Spegel H, Hendrowarsito L, Frenzel A, Fromme H: Effect of classroom air quality on students' concentration: results of a cluster-randomized cross-over experimental study. Indoor Air 2012, 22:378-387.

17. Wargocki P, Wyon DP: The effects of moderately raised classroom temperatures and classroom ventilation rate on the performance of schoolwork by children (RP-1257). HVAC \& R Res 2007, 13:193-220.

18. Wargocki $P$, Wyon DP: The effects of outdoor air supply rate and supply air filter condition in classrooms on the performance of schoolwork by children (RP-1257). HVAC \& R Res 2007, 13:165-191.

19. Seppanen OA, Fisk WJ: Summary of human responses to ventilation. Indoor Air 2004, 14(Suppl 7):102-118.

20. Satish U, Mendell MJ, Shekhar K, Hotchi T, Sullivan D, Streufert S, Fisk WJ: Is $\mathrm{CO} 2$ an indoor pollutant? Direct effects of low-to-moderate $\mathrm{CO} 2$ 
concentrations on human decision-making performance. Environ Health Perspect 2012, 120:1671-1677.

21. Acoustical Society of America: Classroom Acoustics II: acoustical barriers to learning. Melville, NY: Acoustical Society of America; 2002

22. Wargocki P, Wyon DP: Providing better thermal and air quality conditions in school classrooms would be cost-effective. Build Environ 2013, 59:581-589.

doi:10.1186/1476-069X-12-110

Cite this article as: Rosbach et al: A ventilation intervention study in classrooms to improve indoor air quality: the FRESH study.

Environmental Health 2013 12:110.

\section{Submit your next manuscript to BioMed Central and take full advantage of:}

- Convenient online submission

- Thorough peer review

- No space constraints or color figure charges

- Immediate publication on acceptance

- Inclusion in PubMed, CAS, Scopus and Google Scholar

- Research which is freely available for redistribution 